\title{
介護福祉現場における高齢者の食事と支援
}

\author{
松本百合美
}

(新見公立短期大学)

\section{Diet and support for the elderly at sites for nursing care and welfare}

\author{
Yurimi Matsumoto \\ Niimi College, 1263-2, Nishigata, Niimi-shi, Okayama, 718-8585 \\ テ718-8585 岡山県新見市西方1263-2
}

\begin{abstract}
Individualized diet support has become common at sites for nursing care and welfare of the elderly. This approach includes selectable menus, introduction of buffetstyle meals, and treatment of patients with eating disorders and dysphagia using a dysphagia pyramid, with cooperation between dieticians, kitchen staff and care staff. The number of elderly people who will need nursing care is expected to increase, and in this context I would like to propose roles for specialists in nutrition and cooking at sites of nursing care for the elderly. First, these roles include guidance on nutrition and cooking for users of nursing care services at home and support for home care workers. Second, I propose involvement and cooperation in management of nutrition and cooking at small-scale facilities, such as group homes. In nutrition management at nursing homes for the elderly and other long-stay facilities, there is a need to prevent a rapid increase of weight after admission and to provide active dietary approaches to improve constipation. In addition, it is also necessary to develop a diet menu for maintenance and improvement of eating and swallowing. I will show how these roles in combination with experience at nursing care and welfare sites can promote discussion of nutrients and calories, and provide support for diet, a central aspect of daily life, from the standpoint of a nutrition expert.
\end{abstract}

\section{1.はじめに}

食事は生命を維持し活動のためのエネルギー摂取とい うだけでなく，四季折々の食材や献立は，季節を感じさ せ生活に潤いをもたらす。また，2014年，ファイザー株 式会社のインターネット調査「健康寿命と予防に関する 意識調查」1)では, 健康状態が良いと回答した65歳から 70歳の男女600人の分析から, 健康の指標は「执いしく 食べられる」が第 1 位，健康を損なわないコッの第 1 位 が「食生活に気を配る」であった。高齢者にとって食事 は自分の健康状態の目安となり, 同時に健康を維持する ための手段であると認識されている。
2. 高齢者介護現場における食事

（1）利用者の一番の楽しみは「食事」

心身機能の低下で施設を利用している高齢者（以下， 利用者）にとっても，食事は体調を整え，健康を維持。 向上させるために重要なものである。人は加齢にとも なって心身機能が徐々に低下していくが，日常生活活動 （ADL）のうち, 歩行や入浴, 排泄などに比べ，食事は 比較的長く維持され，施設利用者が具体的に実感できる 食べる楽しみや喜びは,「楽しみなこと」の第 1 位であ るといわれている。

しかし，筆者が特別養護老人ホームに就職した30年ほ ど前, 高齢者介護施設など集団生活の場では, 介護職員 や調理員の勤務時間に合わせ, 夕食が17時前後, 朝食は 8 時前後と『早い夕食と遅い朝食』という食事提供が一 
般的であり，利用者は長い夜を過ごしていた。また，決 められた食事時間と下膳時間は, 調理員の退勤時間から 逆算されるため, 介護職員はいかに早く食事を済ませ, 食器を厨房に返すかに腐心する光景もよく目にするとこ ろであった。昭和 47 年の「老人ホームのあり方に関する 中間報告」において，すでに老人ホームは収容の場から 「生活の場」への転換が求められ, 栄養士の配置, 食事 時間の弾力化を図るための職員配置などが盛り込まれて いたが，施設の運営基準等で具体的に示されなかったこ となどから，その後も長く大きな改善はなされなかった。 昭和60年前後になると, 先進的な施設では, 選択メニュー やバイキング方式の採用, 食事時間幅の拡大, 下膳の方 法や時間の弾力化など, 栄養士や調理員の理解と努力, 介護職との連携により取り組まれるようになった。栄養 士が事務所から出て, 利用者の食事をみたり，嗜好調査 を盛んに行うようになったと記憶している。調理器具や 調理方法の開発も進み, 温かい食事は温かくという適温 食の提供やクックチルなどにより選択食実施の追い風に なったと考えられる。

また，1990年代には医療や診断技術・機器の進歩と高 齢者人口の増加により，摂食・嚥下障害がクローズアッ プされるようになる。また，2000年代になると燕下障害 であっても食べやすい食事として，いわゆる嚥下食の開 発が盛んになる。当初はきざみ食が盛んにつくられたが, 食物を小さく刻むことでかえって食塊形成が難しくなる ことがわかり，ミキサー食やペースト食などが開発され た。また，お茶などの水分を摂取しやすいように粉末の 増粘剤が市販されるようになった。はじめは，増粘剤使 用により, 急速に体重が増加してしまったり, 味が変わっ ておいしくないと利用者に拒絶されることも多かったが, 改良も繰り返され，簡易に使用できることから一気に一 般化されていった。栄養士や調理員は，いったん出来上 がった食事をミキサーにかけるとき，ある程度の水分を 加える必要があり, 出汁を使ったり, ゼリー寄せにした りさまざまな工夫を懸命に行っていた。

さらに，本格的な摂食リハビリテーションも始まり， 現在では経管栄養を行いつつ, 再び経口摂取へ移行する 取り組みや, 食べる楽しみの継続としての摂食に取り組 むなど, ST, 介護・看護, 栄養士の多職種が連携した 食事支援が広がっており，その連携のためにも嚥下食ピ ラミッドが活用されている。また，見た目の楽しみにも 対応すべく，ミキサー食をもとの食材のように成形しな おすものや，凍結や圧力を利用して，見た目はそのまま で軟らかくする調理法などの開発もされている。

ある特別養護老人ホームで経験した事例である。咀 嚼・嬹下機能の低下があり, 認知症もある利用者がおら れた。当日は何かの行事食で, 普通食に人には刺身と稲 荷寿司のご馳走メニューであった。しかし，その人の膳 には刺身のきざみが配膳されており，「私に刺身がない」 と言われた。筆者が介護現場で働いていた頃には，こう
いう訴えは介護職にとって非常に辛いものであり，どき りとした場面であったが, その場に栄養・調理部門の職 員がおり，利用者に一言謝って，すぐさま刺身を持って 来られた。利用者はムセもなく, 満足して食された。介 護の現場ではこういう光景はよく見ることで, 普段はム セがある人でも，好きなものはちゃんと食べられること は多い。この施設では日常的に栄養・調理部門の職員が 食事の介護を行っており，ある程度の予測をしてあった のではないかと思われる。利用者の「おいしく, 楽しく 食べる」ことを，作る立場の職員が身近で支え，介護・ 看護だけでない, それぞれの専門性を発揮しつつ, 総合 的な視点から支えていることが実感できる施設も増えて いる。

\section{（2）介護業務における食事}

特別養護老人ホーム等では昭和 38 年の施設創設以来, 栄養管理, 衛生管理や作業効率の面から, 献立・買い物 · 調理・盛付け, 片づけは調理員, 配膳と摂食は介護職が 担うことになっていた。2000年の介護保険導入前後から 始まったケアの単位を小規模化したグループホームやユ ニットケアでは, キッチンが利用者の生活範囲に配置さ れ，効率的な調理をあえて非効率に行うことで，それま で切り離されていた調理や調理に伴うまな板の音, ご飯 の炊ける匂いや副食の香りが, 利用者の生活の中に取り 戻された。利用者は，それまでに培い身につけてきた「生 活の技」を発揮し, 活き活きとした表情を取り戻し, 食 事に対する関心も高まるという効果も実感できた。利用 者とともにがやがやと献立を考え, 買い物に行き, 一緒 に調理する時間は, 介護職員にとっても介護の楽しみを 実感できる貴重な時間でもあった。

しかし，時間が経つにつれ利用者の障害の重度化が進 んでくると, 調理に参加できる利用者が減った。介護職 員は食事以外のケアにかかる比重が大きくなると同時に, キッチンでの調理という業務が残される結果となった。 そのため, 利用者の活動が始まる前の未明に夜勤者が朝 食を用意したり，自動食器洗い機や食器乾燥機にいかに 効率よく食器を入れられるかで, 昼休憩が左右される現 状があるとも聞く。極端な施設では，朝食は介護職員が 作り, 昼食は厨房から運ばれるという状況もある。施設 の方針があるとは承知の上で，栄養・調理がケアの現場 に出ていくという工夫もあってよいのかもしれない。利 用者とともに献立を考えつつ, 栄養面での指導も同時に 行える。筆者は糖尿病を患っている利用者を集めて, 栄 養士と介護職と一緒に調理実習を行っていた経験がある が，普段はとにかく食べたい一心の人でも，栄養士から の栄養指導は非常に熱心に聞いておられた。調理中には, 包丁さばきを褒められたり，思わぬ力を発揮したりと， 非常に盛況だった。食事バランスガイドの絵を見て学習 するより，一緒に作って食べるほうが，利用者も職員も 楽しく学べるのではないだろうか。 
また近年は，食事が外部業者に委託されることも多く なっている。外部委託であればこそのメリットも多いと ころであるが, 外部業者であるからこそ, より意図的に それを食べる利用者の反応を聞き取り，また実際に見る 機会をもつことが欠かせないのではないだろうか。

\section{3．高齢者介護現場で起こっていること}

\section{（1）在宅における食事支援}

近年高齢者のみ, または高齢者の単身世帯が増加して いる。瀬戸らは世帯構成の違いが高齢者の食生活に及ぼ す影響 ${ }^{2)}$ を調査し, 高齢者単独, 夫婦のみ, 三世代同居 の世帯別比較を行ったところ, 高齢者のみの世帯では, 栄養素摂取不足が懸念されることを指摘している。在宅 生活を送る高齢者は, 高齢者夫婦のみの世帯や単身世帯 が多く, 特に中山間地域などの過疎地においては近隣の 商店の減少，公共交通機関の減少などにより，買い物が 困難になる高齢者も多い。

国立長寿医療研究センターが行った『在宅療養患者の 摂取状況・栄養状態の把握に関する調査』 ${ }^{3)}$ では，在宅 療養患者 (990名) のうち, BMI が18.5未満の人が $23.4 \%$ であり，低栄養の人が $36.0 \%$ ，低栄養のおそれの人が $33.8 \%$ と 7 割の在宅療養患者が低栄養のリスクがあると 報告している。また，利用している介護サービスのうち 訪問栄養指導利用はわずか 5 人, 配食サービスを利用し ているのは 81 人である。訪問介護を利用しているのは 438人であり，何らかの食事支援のサービス利用をして いるにもかかわらず，低栄養のリスクが高い人が多いこ とがうかがえる。

訪問栄養指導の利用が少ない要因としては, 医療保険 で対応しているケースもあり，また訪問できる人材の不 足もあると思われるが, 訪問栄養指導そのものが在宅ケ アにかかわる他職種, 他機関に認知されていない可能性 や家族や本人の意向に沿った栄養指導の困難さがあるも のと推測される。食事療法による病態改善だけでなく, 摂食嚥下障害に対応できる食事形態やその調理法, 摂取 そのものが困難になる人への栄養・調理からの対応方法 など，栄養管理の専門職としての知恵を介護現場に発信 していく必要があるのではないだろうか。

また, 在宅生活を送る単身等要介護高齢者の調理は, 訪問介護員がその中核を担っている。しかし，訪問介護 員の買い物の代行についても, 制限が厳しくなり, 家族 等が用意した食材で調理することが求められる。更に, 初任者研修（旧ホームヘルパー 2 級養成課程に相当）に は調理実習の位置づけはなく，訪問介護事業所で自発的 に行われる研修や個人の努力に支えられた調理であると いうのが現状である。訪問栄養指導だけでなく，訪問介 護員や介護職員に対しても，より実践的な栄養・調理の 指導やサポートを行えるような場が必要であり，栄養・ 調理の専門職からも声を上げていただきたい。

\section{（2）急激な体重増加}

在宅から特別養護老人ホームなどへ入所した利用者の 多くは，家族から「元気になった。」と言われることが 多い。特に, 単身や高齢者夫婦のみであった利用者は,「色 つやがよくなった。「ふっくらした。」と言われること が多い。これらは，入所したことで自動的に行き届いた 食事が提供され，体力が回復してくるためだと考えられ る。食事の大切さを実感する場面である。

しかし, 中には急速に太ってしまう人もいる。入所当 初は元気になって力もわいてくるが, そのままのペース で体重が増加すると, 膝関節症などがある人の場合, 歩 けなくなってしまうこともある。出てきた腹部が邪魔を して，衣服の着脱が難しくなったり，ズボンが上げにく くなったりする人もいる。適切な栄養管理が行われてい るにもかかわらず，生活機能が低下するのは，運動など の活動によるカロリー消費が少ないことが原因であるこ とは自明のことである。介護職員は適切な運動機会を提 供するように努めなければいけないが，利用者の多くが， 身体的な障害や疾患があり, 動きにくくなってしまえば さらに運動しにくい状態が起こるという悪循環に陥って しまう。前述したように, 入所前, 在宅生活では低栄養 の傾向があった利用者は多いと考えられる。入所前後の 栄養摂取量と運動機能面を把握し, 急速な体重増加を起 こさないように, 生活活動量の観察や測定など一人ひと りに応じた段階的なカロリー増などの栄養管理を, 栄養 士と介護・看護職の連携で行っていく必要がある。

\section{(3) 高齢者の便秘}

高齢者の消化器は他の器官に比べて, 比較的維持され るといわれる。しかし，高齢になると便秘を抱える人は 多い。高齢者の約半数が便秘あるいは下剂を使用してい

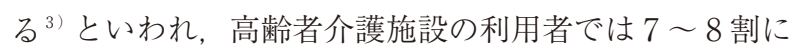
のぼるといわれる。

便秘の原因として, 食事や水分摂取量の低下, 腸の蠕 動運動の低下, 落ち着けない排便環境などがある。毎日, 処方された下剤を服用して，だらだらと便が続く人や， 排便のない日が 3 日続くと, 座薬や浣腸で排便を促すと いうパターンが多い。下剤を服用している人の中には, 便がだらだらと続くために，入浴はいつも最後に回され， 浴槽につかることができない人もいる。

便秘をしている利用者の食事量や水分量は問題のない 場合も多く，落ち着いた排便環境と排便習慣を取り戻し てもらうための介護職員の役割は重要である。同時に,

看護・医療との連携も不可欠である。栄養面においては, 食物繊維や乳製品の摂取が昔から便秘予防に効果がある とされており，日々改善のための工夫をされている。咀 嚼や熿下機能に問題を抱える人も多くなり, いかに軟ら かく，飲み込みやすくという工夫がされている。看護 · 医療職, 聴覚言語療法士や介護職員等とともに, 多職種 の有機的な連携で, 高齢者の便秘解消, 薬剂依存傾向の 
改善の取り組みをしていくことが，なにより利用者一人 ひとりの心地良い生活を守ることにつながると考えてい る。

\section{（4）咀嚼・嶼下機能の維持・向上のための食事}

一方, 前述した長寿医療研究センターの調査では,「ど んなものでもたいてい噛める」「たいていの物は噛める」

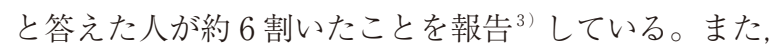
日本歯科医師会 ${ }^{4)}$ は, 「歯と口の健康週間」で毎年標語 をつくっているが,「広げよう噛むから始まる健康づく り」(2010年),「かみしめる生きる喜び歯とともに」(2009 年）など，健康と噛むことの大切さを表したものが多い。 軟らかくて食べやすいことも大切であるが，何でも噛め ることを自慢にする高齢者も多く, 摂食嚥下ピラミッド の作成や活用, 咀嚼・曣下障害のある人への細かな食事 形態が開発されてきたように, 咀嚼・䜩下機能を維持・ 向上するためのプログラムも今後開発する必要があるの ではないだろうか。歯科医師や歯科衛生士，言語聴覚療 法士等と連携を取りつつ, 食品の開発などに関しても検 討されることを期待する。

\section{4. 食べることは生きること}

介護福祉士は，「人の生活を支える」仕事である。人 の生活はいうまでもなく，さまざまな側面から成り立っ ている。多くの専門領域の知識や技術を集結しつつ, 現 実生活を生きる人を支える仕事である。そうした介護福 祉という職の奥深さに魅かれ，人の人生の最後の何年間 かを，何かの縁でかかわることを許され，日々『命の輝 き』を見続けてきた。利用者の臨終に立ち会うたびに, 私と過ごした時間の中で，どんな笑顔を見せてもらった か，どんな笑顔を引き出せたかと振り返ることにしてい た。そんな中で，食べることにまつわる利用者とのエピ ソードの多さに気がつく。

利用者と「たまには弁当屋の弁当が食べたい。」とい う話が持ち上がった。弁当屋のチラシを見ながら，それ ぞれが好みの弁当を注文することになった。失語があり， 自分の歯がなく義歯も嫌って装着せず，普段は刻み食を 食べている男性が，『うな重弁当』を指さし，強く領く。 筆者は当然のように，もう少し食べやすそうなものを薦 める。しかし，指先は『うな重弁当』から離れない。「ウ ナギを刻む」ことを約束して，その場は決着するが，案
の定ウナギは刻まれないまま男性の胃の中へ，男性の満 足そうな笑顔が思い出される。

糖尿病のある女性利用者 3 人組の仲良しグループの人 たちは，施設に 2 週間に 1 回くる出張売店で山ほど扮菓 子を買い込み, 職員に隠して一度に食べては後攸する人 たちだった。そこで筆者が提案したお菓子の共同購入を 決め， 3 人分をひと盛りにしたおやうを開始したところ， 皿に残りが少なくなると，「これは，あなたの分，私は もういいから。」と優しさと社会性を発揮し筆者を驚か せてくれた。

新見市にあるグループホーム花みずきでは，利用者に 提供する食事は介護職員が作っている。野菜の皮をむい だり，下ごしらえをするのを利用者が手伝っておられた。 「扔上手ですね。」と声をかけると「何を大げさな…」。「「楽 しいですか。という問いかけには「これぐらいのこと， 楽しいも何もない。と笑って扮られた。調理などは長 年家事をしてきた女性にとっては，普通の生活なのであ る。建物のわきには畑があり, 天気の良い日には利用者 も出てきて, 野菜作りを一緒に行ったり,「農業指導」 をして下さるそうだ。近隣の住民からは，自分の家でと れた野菜や苗物の拉すそ分けも多いという。こうしたこ とも, 日常生活であり, 高齢者にとっては普通の近所付 き合いの範囲である。施設における「生活の質」を問う 時代であるが，食べることは生きることであり，食べる 楽しみは生きる喜びにつながっている。食事は栄養素や カロリーだけではなく, 人の暮らしの中心にある。食の 専門家として, 介護福祉の現場, 介護職員への支援も含 めて, ご活躍を打願いしたい。

\section{文献}

1）ファイザー株式会社：高齢者の「健康寿命と予防」に関 する意識調查 (2014), http://www.pfizer.co.jp/pfizer/company/ press/2014/2014_12_16.html（2015.11.12閲覽）

2）瀬戸美江, 塩谷知華, 澤田崇子, 藤本健四郎：世带構成 の違いが高齢者の食生活に及ぼす影響, 日本調理科学会誌, 40(1), p. 15-21 (2007)

3）国立長寿医療研究センター：在宅療養患者の摂取状況 栄養状態の把握に関する調查研究報告書 (平成 24 年度保健 健康增進事業)（2013）

4） 日本歯科医師会：歯と口の健康週間 標語一覽, http:// www.jda.or.jp/enlightenment/poster/backnumber.html (2015. 11. 12閲覧)

本稿は, 第51回大会における主題講演をまとめたものである。 